\title{
Team Effectiveness in Non-Governmental Organizations (NGOs) Projects
}

\begin{abstract}
The incorporation of team context into research and practice regarding team effectiveness in NGOs projects is a constant challenge. The research seeks to address the gap and identify the critical determinants of team effectiveness in projects undertaken by non-governmental organizations. Using a systematic process, the study involved both literature and focus group discussions to generate the required items. A total of 157 respondents (Team Members and Team Leaders) were part of the study that filled the questionnaires. Using exploratory factor analysis followed by confirmatory factor analysis, both convergent and discriminant validity was established. The present study found that team effectiveness in NGO social projects has a total of seven dimensions namely: Inter team coordination, community social linkage, team performance, knowledge, skills, and attitudes, leadership communication and engagement, decision making and information sharing, and team formation. There is a significant lack of research on team effectiveness in NGO projects. Where considerably large proportion of research on team effectiveness has focused on the corporate sector, the non-governmental teams have been neglected. This study clearly highlights the determinants that make up team effectiveness in NGOs. The determinants identified will help to specifically look at the effectiveness of teams in NGO projects. The study would help NGOs identify the dimensions in which they may be performing in a weaker manner and direct their energies in improving the factors.
\end{abstract}

Keywords: Non-governmental organizations, Team Effectiveness, Social Projects

\section{Introduction}

Project delivery is an inherently team based activity and the effectiveness of these teams has been recognized in many sectors such as construction, manufacturing, banking, services and other works as a factor in delivering successful project outcomes (Azmy, 2012; Levi, 2007). Project teams enable organizations to be innovative and flexible while maintaining a high level of performance (Hüttermann \& Boerner, 2011). Teams play pivotal role in the organizational structure and compliment organizational strategy. Furthermore, teams are imperative for organizations to respond to the dynamic workplace, economics and global demands (Kozlowski \& Ilgen, 2006). Effective and efficient teams can be utilized to attain organizational goals (Randeree \& Ninan, 2011) whereas ineffective teams can obstruct an organization's progress and cause rework, wastage of resources, and loss of valuable time (Ross, Jones, \& Adams, 2008). Although, every organization has project teams in some capacity, there are still significant research gaps in the dimensions of project team effectiveness (Klein, 2012, p. 53). Understanding the dimensions of project team effectiveness can result in improved performance (Levi, 2007) by the establishment of conducive working relationships (Demkin (2008). Thus further research studies are essential to recognize the factors that determine team effectiveness as a move towards team improvement.

This issue is critical for Non-governmental organizations or NGOs, defined as not for profit, non-political, non-governmental enterprises which are accountable to their stakeholders and engaged in welfare and socio-economic development of society. These organizations are growing rapidly in both scale and range of activities. Many of their activities and interventions are project based (Ika, Diallo, \& Thuillier, 2012). However, it is only recently that researchers 
have started to examine the project management (PM) practices work carried out by nongovernmental organizations (Golini, Kalchschmidt, \& Landoni, 2015).

NGO projects tend to face uncertainty in evaluation of outcomes (Ronalds, 2012) arising from the nature of objectives and the heterogeneous group of stakeholders involved. Business projects are designed to deliver beneficial change or added value to the organization (Hernandez \& Cormican, 2016) while NGO projects are aimed at social change to meet the social needs and actualize social vision (Brown \& Korten, 1989). In the case of the former, the outcomes such as commercial success can be agreed upon and measured using quantitative metrics. Development projects by NGOs are intended to alleviate poverty and improve standard of living, protect the environment, protect basic human rights, build capacity and provide basic physical and social infrastructure. The differentiating feature is that these social and humanitarian objectives are much less tangible, with deliverables less visible and measurable in comparison to infrastructure and industrial projects (Khang \& Moe, 2008).

The heterogeneous stakeholders involved in NGO projects is another source of uncertainty (Youker, 1999). Industrial and commercial projects may have two key stakeholders - the client, who is the financial sponsor of the project and the implementing partner. Developmental projects are delivered by sponsors under varied forms of funding and collaboration, for instance through bilateral agreements with recipient governments or through a “middlemen” - normally a non-governmental organization (NGO) (Crawford \& Bryce, 2003; Zetland, 2010). They therefore involve the funding agency, the implementing unit, and the target beneficiaries who benefit from the project outputs but most commonly do not pay for the projects i-e the community or the society. Social change projects may also face resistance from the community or society whose existing beliefs and values may be affected. The benefits of these interventions may be disputed by those they intend to serve, resulting in uncertainty about their success.

Project teams in NGOs operate in environments where there may be little formal infrastructure (Rahman, 2007). Teams delivering these projects are usually multi-disciplinary in nature, requiring people with different skills within and across the organization who must share knowledge for optimum decisions (Diallo \& Thuillier, 2004). Apart from the intra-team coordination, there has to be a cordial relationship between the team and the society in which the team is operating, even with those who may oppose or be skeptical about the outcomes of interventions (Herman \& Renz, 2008). While there is need for effective NGO project teams as these organizations are assessed by their ability to deliver on development goals, NGO projects suffer from high levels of failure. Yalegama, Chileshe, and Ma (2016) noted that the substandard performance of development projects has been a concern throughout development project history. There is an increasing demand on the non-governmental social projects to meet the performance demands. Teamwork has been found as a critical factor in success of projects undertaken by international non-governmental organization (Shaw et al., 2002; Steinfort \& Walker, 2007). The need for effective teamwork is further emphasized by existing research that has found competent project team with right attitude as significant factor in developmental projects (Khan, Thornton, \& Frazer, 2000; Khang \& Moe, 2008; Struyk, 2007; Vickland \& Nieuwenhuijs, 2005). 
Multi-dimensional tools have been utilized to evaluate team effectiveness in different types of organizational settings ranging from schools, university medicine, construction to other industries (Brewer \& Mendelson, 2003; Castka, Bamber, \& Sharp, 2003; Gibson, ZellmerBruhn, \& Schwab, 2003; Gordon et al., 2016; Guchait, Lei, \& Tews, 2016; Hoegl \& Gemuenden, 2001; Kirkman \& Shapiro, 1997; McComb, Kennedy, Green, \& Compton, 2008). There are a number of uni-dimensional scales to measure team effectiveness (Alexander, 1985; Child \& Shumate, 2007; Kwofie, Alhassan, Botchway, \& Afranie, 2015; Parker, 2016; Santos, Caetano, \& Tavares, 2015; Yang \& Chu, 2012). The criterion measures, and especially performance indices, however, are often idiosyncratic and organizationally/context specific (Kirkman \& Shapiro, 1997).

NGO teams have been identified as a factor in project success (Khan et al., 2000; Khang \& Moe, 2008; Lin Moe \& Pathranarakul, 2006; Shaw et al., 2002). Project team interactions and their effectiveness can vary with context (Finn, Currie, \& Martin, 2010). Since NGOs experience differing types of uncertainty and play a key role in building the capacity of civil society (Armony, 2008; Navarro-Flores, 2011), there is a need to examine the components of effectiveness of in NGO project teams. The objective of this research is to identify the key dimensions of an effective team working in NGO projects. Using a mixed methods approach that combines a focus group with CFA, this paper identifies the dimensions of NGO project team effectiveness using data from NGOs in Pakistan.

\section{Literature Review}

Comment [D1]: Reviewer 1 Comment: - In the introduction, the research question should be presented with the research objective

Objective and Question provided

\section{Team Effectiveness}

Gladstein (1984) defined team effectiveness in terms of performance and satisfaction. Hackman (1990) extended this definition to include the extent to which it meets requirements in terms of quantity, quality, and timeliness (performance); improves members' ability to work as a group (behavior), and the experience contributes to individual satisfaction (attitude). Mohrman, Cohen, and Mohrman (1995) added the dimension of interdependent functioning. In combination these definitions highlight three aspects of team effectiveness (Cohen \& Bailey, 1997; Ulloa \& Adams, 2004):

- Performance effectiveness (productivity, efficiency);

- Attitudinal outcomes (satisfaction, commitment and trust in management); and

- Behavioral outcomes that included absenteeism, turnover or safety.

Project team performance can be defined as the extent to which a team is able to meet established quality, cost, and time objectives (Schrader \& Göpfert, 1996) and the ability to create outputs and perform at a level that met or exceeded client and/or stakeholder standards and expectations (Wageman, Hackman, \& Lehman, 2005). Attitudinal effectiveness refers to the team members' psychological state or whether the team experience contributed positively to individual team members' learning, well-being and development (i.e., the team members became more capable).Behavioral effectiveness includes team member performance, citizenship behavior, creativity (Chou, Wang, Wang, Huang, \& Cheng, 2008) along with the development of capacity for the team to work together in the future. 
Where previous definitions of team effectiveness focused on team performance, member's attitudes and behaviors, Volmer and Sonnentag (2011) conceptualized team effectiveness as the combination of team and task functions. Here, the team functions are the facilitating interaction patterns amongst the members, for e.g. cohesiveness, cooperation etc., and the task functions are actual activities performed to accomplish the tasks, for e.g. autonomy, accountability, etc. Team functions cover the attitudinal and behavioral aspect identified in the previous definitions while task function focus on the performance of the team through accomplishment of tasks. Overall, these definitions suggest that teamwork effectiveness is a multi-dimensional construct determined by performance, attitude, and behavior. It is however important to note that these dimensions are not equally important and significant for each type of team. The importance of each one is concerned with team values and activities (Piña, Martínez, \& Martínez, 2008). The definitions are inconclusive and have evolved over time. Since, the definitions may change with the change in the context in which teams may be studied.

Existing research has highlighted the role of teams in attaining project success (Khan et al., 2000; Khang \& Moe, 2008; Todorović, Petrović, Mihić, Obradović, \& Bushuyev, 2015). In case of NGO projects inclined towards public projects, team members effectiveness has been found to have a significant impact (Lin Moe \& Pathranarakul, 2006). A study of Indonesian NGOs by Shih and Putri (2016) indicates that team effectiveness has a significant positive effect in the speed of response to disasters (Sheppard, Tatham, Fisher, \& Gapp, 2013). Team effectiveness in NGO is not only required to produce results for the community(Zhu \& Purnell, 2006), but supports the development of relationships with donors (Heap, 2000) who provide resources.

Literature has identified a number of determinants that create an effective team that leads to project success in NGO projects. These include team cohesion (Lin Moe \& Pathranarakul, 2006), consultation with stakeholders (Lin Moe \& Pathranarakul 2006; Khang \& Moe, 2008; OECD, 2015), capacity to solve problems (Belout \& Gauvreau, 2004), communication skills to resolve conflicts and local knowledge (Brière, Proulx, Flores, \& Laporte, 2015), transparency and accountability (Ramachndran \& Walz, 2012; Tierney, 2012), role clarity (Moe \& Pathranarakul 2006; Levie, Burke, \& Lannon, 2016) and needs of target beneficiaries (Levie, Burke, \& Lannon, 2016). Supporting teamwork requires a strong theoretical and empirical understanding of what teamwork is, which depends in part on the appropriate measurement of teamwork (Valentine, Nembhard, \& Edmondson, 2015).

\section{Measurement of Team Effectiveness}

Team effectiveness has been measured using both uni-dimensional (Santos et al., 2015) and multi-dimensional approaches (Mathieu, Maynard, Rapp, \& Gilson, 2008). Unidimensional scales have been applied in product development (Parker, 2016) construction (Kwofie et al., 2015; Yang \& Chu, 2012) and medicine (Friesen, Vidyarthi, Baron, 2008).

A number of multi-dimensional scales have been designed and developed to measure team effectiveness. Some of them are discussed in this section. It is important to note that much of the scales are context specific. One of the earliest attempts at measuring teamwork was from Campion, Medsker, and Higgs (1993) who proposed a scale to ascertain work group effectiveness having 19 different dimensions clubbed into five themes namely job design, 
interdependence, composition, context, and process. Gibson, Zellmer-Bruhn, and Schwab (2003) in their study of team effectiveness in multinational organizations identified Goal, Customer, Timeliness, Quality, and Productivity as key dimensions. Wageman, Hackman, and Lehman (2005) conducted a study in diverse organizations to develop a team diagnostic survey for research on team behavior and performance and identified process criteria and team social process as two main dimensions. Bateman, Wilson, and Bingham (2002) developed a team effectiveness audit tool with four factors namely effectiveness of team outputs, team identity/team synergy, clarity of performance objectives, and team role clarity. It is noteworthy that they satisfied all criteria for psychometric validity (Valentince, Nembhard, \& Edmondson, 2012). Hutchinson et al (2006) studied hospital and primary care trusts and identified two dimensions of teamwork namely Input into decisions and collaboration with other staff and Information handover. Similarly Gordon et al. (2016) developed a multidimensional selfassessment team work tool to assess teamwork among nursing and medical students. They identified Teamwork coordination \& communication and Information sharing and support as key determinants for team effectiveness. A more generalized multi-dimensional construct has been developed by Hoegl and Gemuenden (2001) for measuring team work quality. The model examines attitudinal and behavioral dimensions of team effectiveness which can indicate the quality of collaboration in teams. However, the model does not examine team performance (Castka et al., 2003),. Similarly, Kirkman and Shapiro (1997) proposed a globalized scale to evaluate team effectiveness in multi-national corporations and identified Productivity, Quality, Costs, Safety, and Customer Satisfaction as the determinants of team effectiveness. Senior (2007) developed a teamwork survey instrument using 220 members of management teams working in private and public-sector organizations and found five factors with one factor have three sub-factors namely vision, task orientation, and three sub-factors namely participative safety, support for innovation, interaction frequency. Guchait et al. (2016) measured team effectiveness in hospitality industry through team satisfaction and team performance, behavioral dimension of team effectiveness was not part of their study. McComb et al. (2008) assessed project team effectiveness industrial projects through development of scale based on existing measures. Brewer and Mendelson (2003) developed a systematic methodology and measurement for assessment of team effectiveness in engineering/business student teams using three outcomes: creativity, collaboration and productivity.

Much of the existing empirical studies investigating team effectiveness have typically included team outcome measures that are organization specific or unit specific with much of the focus on team performance that cannot be equated to the team effectiveness. Although, there have been other studies that address team effectiveness. However, the primary focus of these are premised on specific concerns or theoretical foundations - usually associated with unidimensionality related to the activities and elements of team effectiveness and not scale development. Any attempts to measure team effectiveness have been ad hoc at best with the exception of Gibson et al. (2003) in which they conceptualize a multi-dimensional construct of team effectiveness in multinational corporations. Another study by Wageman et al. (2005) confirmed team effectiveness as an important antecedent of project performance and developed a generalized scale to measure team effectiveness. It is now widely accepted that teamwork varies with context (Finn et al., 2010; Mueller, 1994; Mueller, Procter, \& Buchanan, 2000; Procter \& Currie, 2004). Gibson et al. (2003) strongly contend that explicit consideration of team context is critical. Furthermore, Krishna and He (2015) also notes that each organizational context is unique and thus requires a contextually appropriate solution to enhancing team innovation and 
effectiveness. These researchers acknowledge that teams are not socially isolated entities and that both internal and external processes have important implications for team performance. Non-governmental organizations have complicated team-based structures, with teams required to coordinate both on and off field. Team work in social projects is different in comparison to other projects. Since, in the societal context - humanitarian aid or capacity building as in any intercultural context requires specific skills and abilities such as special knowledge of human relationships as these projects bring people together from different cultures, mentalities, and backgrounds (Simkhovych, 2009). Existing literature has focused more on for profit organizations despite the fact that non-governmental organization invest heavily on projects for societal development. Hence, there is a need to examine Project team effectiveness in specific contexts such as NGOs. The concept of teamwork has not been meticulously investigated in NGOs, the present study would help in developing an understanding of what constitutes an effective team in projects undertaken for the betterment of society.

Table 1. Team effectiveness scales and dimensions

\begin{tabular}{|c|c|c|}
\hline Dimensions & Setting & Source \\
\hline $\begin{array}{l}\text { Themes: job design, interdependence, } \\
\text { composition, context, and process. }\end{array}$ & $\begin{array}{l}\text { Employees and managers from } \\
\text { financial organizations }\end{array}$ & $\begin{array}{l}\text { Campion, Medsker, and } \\
\text { Higgs (1993) }\end{array}$ \\
\hline $\begin{array}{c}\text { Productivity, Quality, Costs, Safety, and } \\
\text { Customer Satisfaction }\end{array}$ & Self-Managed work teams & $\begin{array}{c}\text { Kirkman and Shapiro } \\
\text { (1997) }\end{array}$ \\
\hline $\begin{array}{l}\text { Communication, Coordination, Balance of } \\
\text { member contributions, mutual support, } \\
\text { effort, and cohesion }\end{array}$ & Software development Teams & $\begin{array}{l}\text { Hoegl and Gemuenden } \\
\text { (2001) }\end{array}$ \\
\hline $\begin{array}{l}\text { Effectiveness of team outputs, team } \\
\text { identity/team synergy, clarity of } \\
\text { performance objectives, and team role } \\
\text { clarity. }\end{array}$ & $\begin{array}{l}\text { Acute and community health and } \\
\text { social services }\end{array}$ & $\begin{array}{l}\text { Bateman, Wilson, and } \\
\text { Bingham (2002) }\end{array}$ \\
\hline Creativity, Collaboration, and Productivity & Engineering/business student teams & $\begin{array}{l}\text { Brewer and Mendelson } \\
\text { (2003) }\end{array}$ \\
\hline $\begin{array}{c}\text { Goal, Customer, Timeliness, Quality, and } \\
\text { Productivity }\end{array}$ & Multinational Organizations & $\begin{array}{l}\text { Gibson, Zellmer-Bruhn, and } \\
\text { Schwab (2003). }\end{array}$ \\
\hline $\begin{array}{c}\text { Process criteria: effort, performance } \\
\text { strategy, and knowledge and skills. Team } \\
\text { social process: quality of interaction and } \\
\text { relationship satisfaction }\end{array}$ & Diverse organizations & $\begin{array}{l}\text { Wageman, Hackman, and } \\
\text { Lehman (2005) }\end{array}$ \\
\hline $\begin{array}{l}\text { Input into decisions and collaboration with } \\
\text { other staff and Information handover }\end{array}$ & $\begin{array}{l}\text { Acute hospital trusts and nine } \\
\text { primary care trusts }\end{array}$ & Hutchinson et al. (2006) \\
\hline $\begin{array}{l}\text { Vision, task orientation, and three sub- } \\
\text { factors namely participative safety, } \\
\text { support for innovation, interaction } \\
\text { frequency. }\end{array}$ & Public and Private organizations & Senior (2007) \\
\hline Team Satisfaction and Team Performance & Hospitality industry & Guchait et al. (2016) \\
\hline $\begin{array}{l}\text { Team work coordination \& } \\
\text { communication and Information sharing } \\
\text { and support }\end{array}$ & Nursing and medical Students & Gordon et al. (2016) \\
\hline
\end{tabular}

\section{Research Methodology}

A mixed method approach has been taken to examine the dimensions of NGO project team effectiveness. The approach has been suggested by Killen, Jugdev, Drouin, and Petit (2012) as it enables the iterative examination of a phenomenon in its context, which is of value for examining emerging Project management phenomena such as team effectiveness.
Comment [D2]: Reviewer 1 Comment: - In the literature review the dimensions of the conceptual framework and the research variables should be better presented, for example, with a diagram or a table

Tables has been added that identifies the team work dimensions from existing literature. 


\section{Research Setting}

NGOs play an active role in developing activities and vulnerability reduction particularly in the developing countries (Nanthagopan, Williams, \& Page, 2016). According to Dedu, Staicu, Niţescu (2011) NGOs mainly work in countries which have limited institutional capacity primarily due to emerging nature of the economy. As a result of the economic status of the country, the state may have limited infrastructure facilities to aid the people, this thus leads to involvement of different NGOs to provide functions which in a developed country are provided by the state. One of the reasons for the growing role of NGO in the developing world is highlighted by Baviskar (2001) who argued that the growing eminence of NGOs in development is strongly related to the declining legitimacy of the state. Furthermore this is based on a new found expectation that NGOs are better placed as compared to the state bureaucracy to provide leadership for social reconstruction of societies of the developing world particularly (Ghosh, 2009). The present research was conducted in Pakistan. Pakistan is a developing country with a giant network of NGOs operating in different fields like rights, health, education, women empowerment, and development. According to Shah (2016) the number of active NGOs fall between 100,000 to 150,000 , this is revealed by a certification organization for NGOs named Pakistan Centre for Philanthropy (PCP). This means that there is at least one NGO per 2,000 people. It is therefore important to examine how projects are managed in this context. Existing research in the context of Pakistan has identified issues in project planning, resulting in projects failure to meet their goals (Ullah et al 2017). Some of underlying causes of these problems have been linked to the low level of competency of project teams (Bredillet et al 2008). However, while these issues have been examined in the construction and public sector and due to the importance of NGOs in the Pakistan context, this research examines project team effectiveness in NGOs. For this study team leaders and members working in different NGOs within Pakistan were approached for initial focus group discussions and final data collection.

The steps followed in the present research are as follows

Step 1 - Focus Group Discussion: The present study involved different set of stakeholders who were consulted for development of an instrument to measure team effectiveness in NGO social projects. The NGO projects that were contacted for focus group discussion are presented in appendix 1. Team Leaders and members were consulted from a total of six different projects. One team leader was selected from each of the NGO projects along with the two team members except for Children support project, in which there was 1 team leader and 1 team member. NGO project team members and team leaders were consulted for their opinion about their perspective on team effectiveness using semi structured interview questions. The interview protocol was developed using literature (Cohen \& Bailey, 1997; Gibson et al., 2003; Hackman, 1990; Wageman et al., 2005) (see Appendix 2). Community members were also consulted for their intake on how the members of NGOs should behave and perform while working on social projects. Each of the focus group discussions started off with clearly highlighting the objectives of the research and the need for the discussions. The guideline used for conducting the focus group discussion was conducted under the guideline attached in the Appendix 2. Notes were
Comment [D3]: Reviewer 2 Comments: Where the People Came from

\section{Research Locale Added}

Comment [D4]: Reviewer 1 Comments: Countries in which NGO work should be presented.

Type of countries in which NGO work is presented along under research locale and for the present study Pakistan, a developing country was the research locale
Comment [nw5]: Fahim Ullah, Muhammad Jamaluddin Thaheem, Siddra Qayyum Siddiqui, Muhammad Bilal Khurshid, (2017) "Influence of Six Sigma on project success in construction industry of Pakistan", The TQM Journal, Vol. 29 Issue: 2, pp.276309, doi: 10.1108/TQM-11-20150136
Comment [D6]: Reviewer 1 Comment: The repartition of respondents in NGOs activities sectors should be also indicated.

Details added about team leaders and members who participated in the discussion from different projects. 
taken during each of the discussions. Based on the ideas/key points that were presented pertinent to the team effectiveness from team members and team leaders during the discussions are highlighted below.

\section{Team Members}

There are different factors that determine the effectiveness of team, some of which are goal achievements, inter relationship of team, work atmosphere, and efficiency of work.

Communication skills, relationship building, PR Development

Efficiency, collaboration, unity, competency, and tolerance

Positive attitude towards work, interpersonal communication, and goal oriented

Characteristics of an effective team are that they work well together and each person can contribute efficiently to the team and they work together to contribute as a team. A team must be able to meet the targets and achieve the goals together, even if there are disagreements, they still work together and work well.

Social projects require people who are more patient in facing people from the community and people that aren't representatives of very large corporate organizations. These people require characteristics of patience, caring, truth telling, honesty, hardworking etc.

Show loyalty, sincerity, has strong moral values with strong inter personal communications, improved inter personal relationships, and good relationship with social community in the field.

The team needs to have patience, caring nature, with the ability to dedicate efforts towards the society and demonstrate that they're working and thinking about the matters in society. Furthermore, the team needs to have the ability to show experience and skill in order to give confidence to the society.

\section{Team Leaders}

Professional team playing individuals who can work well in the team. They should show professional behaviors at all times. They should abide by all of the rules and make sure that they follow the NGO's attitude and targets and show strength throughout.

The way in which they work together, whereby each member of the team is ideal for a certain area, or skilled in a certain area where others aren't, the unique experience contributes greatly to the team.

Positive, outgoing people who like to make a difference to the world. They must be hard working and be patient, and know that results may not happen straight away.

Strong inter personal relationships, goal oriented, good followers of planned objectives, with good interpersonal communication
Comment [D7]: Reviewer 1 Comments: These quotes should be contextualized according to respondent's categorization.

Thanks for your comments. Quotes contextualized based on Team Members and Team Leaders 
Individual members should give strong though to creative solutions that could address a problem. Everyone should keep their eyes on the eventual goals of the project and team goals should be understood by everyone.

Targets are met, furthermore, people should also work well together as a team and there should be little conflicts. If there are conflicts they should get through it together and show support throughout.

When team communicates their progress and by matching standard/ principles which are established before starting work

Patience and pleasant attitude, effective planning, communicating the key outcomes and progress from the project or plan which is being executed for the society/target demographic area and understanding and giving respect to local social norms, values \& laws.

Step 2 - Keywords Generation and Deriving Items: Upon completion of the focus group discussions, notes were analyzed to identify the keywords that emerge from each of the focus group discussion. These keywords were compared to findings in research articles (Guchait et al., 2016; Loughry, Ohland, \& Moore, 2007; Macaulay \& Cook, 1995; Rao, 2016; Shea \& Guzzo, 1987; Sundstrom, DeMeuse, \& Futrell, 1990; Unger-Aviram, Zwikael, \& Restubog, 2013; Wageman et al., 2005; Wang, MacCann, Zhuang, Liu, \& Roberts, 2009). Initially a total of 81 keywords were noted. The keywords were then used to derive statements. A total of 81 statements were formulated based on the keywords. A set of discussion was held with the academicians and team leaders, and members to identify if any of the statements are repeated or there are common themes in the questions. Academicians also focused if any of the items required any changes in the wording. Finally, upon completion of this stage a total of 56 items were left.

Step 3 - Categorization: Once the statements were drafted, the researchers worked independently to categorize the items into different dimensions. A total of seven dimensions for team effectiveness in NGO social projects were identified. Furthermore discussion was held with senior academicians and team leaders to highlight if there were any errors in the categorization, and should any statements need change in categorization. Finally, upon completion of this stage the 56 items were categorized into seven different categories. The items were also presented to an English expert for checking any grammatical mistakes.

\section{Initial Data Collection and Purification}

After the generation of initial set of items and their categorization, data was collected for a pilot study. A total of 34 respondents participated in the study. A draft questionnaire was proposed. The participants were also allowed to make comments on the questionnaire. Five statements were removed at this stage since they showed low reliability and based on the comments of the team leaders and members involved in the initial data collection and purification. At the end of this stage the instrument had a total of 51 items.

\section{Respondents Profile}


Team leaders and members working on different society related projects for various NGOs participated in the study. A total of 197 respondents from different projects participated in the study, out of which 157 were found complete, yielding a response rate of $79 \%$. Out of 157 respondents, $142(90.4 \%)$ were male while $15(9.6 \%)$ were female. A total of $56(35.7 \%)$ of respondents were in the range of 20-29 years, 73 (46.5\%) were between 30-39 years, 12 (7.6\%) were in the 40-49 years range while 16 (10.2\%) were in the range of 50-59. Team leaders and members both were surveyed during the study. A total of 139 (88.5\%) respondents were team members while 18 (11.5\%) respondents were team leaders.

\section{Data Analysis and Results}

The initial pool of 51 items generated based on the literature and group discussions is presented in table 2. Data was collected on these mentioned statement and was initially subjected to exploratory factor analysis whose results are presented in the next section.

Table 2. Items for Team Effectiveness in NGO projects

\begin{tabular}{l} 
Team Effectiveness in NGO Projects \\
\hline Items \\
\hline Team members were pro-active \\
Team members were accommodating towards each other's needs \\
There was significant Coherence/Unity among team members \\
There was harmony in the team \\
Team Members were responsive to the needs of the co-workers \\
Team Members shared and understood each other's feelings \\
Team Members were quick learners \\
Team member showed zeal for continuous improvement \\
Team members wanted to make a difference to the society \\
There was no significant conflict reported with the community \\
Team Members had knowledge about community and society \\
Team members showed respect towards community and their culture \\
Team developed good relationship with the community \\
Team Understood Issues and challenges in the Society \\
Team was Self-Motivated to give something back to the society \\
The team was able to attain their targets in time \\
The society for which the project was intended was happy with the project \\
Team members showed integrity in using the resources \\
No significant member left the team during the course of the project \\
Resources were used adequately with minimal losses \\
Team members were not overloaded with work \\
Team Members provided constant update on the progress towards tasks \\
The team collectively was able to bring out a positive change in the society through the project \\
Team members were found to be Emotionally Intelligent \\
Team members showed Varied and complimentary Skillset/Competencies required for the project \\
Members were sincere towards the team
\end{tabular}

Comment [D8]: Review Comments: Ideas/key points that are presented in the methodology should be presented in the data analysis/results section.

Table added that shows the items based on the ideas/key points from the literature and focus group discussions 
Members realized their potential and worked to the best of their abilities

Team members believed in healthy competition

Team members were held Responsible/Accountable for their tasks

Team members enjoyed mutual Coordination

Team members respected each other

Team members had good Communication Skills

Leaders gave realistic challenge to the team members

Leaders motivated sub-ordinates to achieve the project objectives

Leader continuously followed-up the pace of activities

Leaders took members opinion and discussed about problems in the field

Leaders connected with stakeholders in the society

Leader delegated power and responsibility to work independently

Team members collaborated with each other to attain the task

Team members gave their input when required in the decision making process

Team members shared their knowledge and experiences

Team members tried to reach Consensus on issues

Team members shared their ideas in an open environment

Team member actively participated in the team tasks

Clear Direction and Focus was established right at the start of the project

Proper Selection process was undertaken to form the team

Each of the team members clearly understood their job right at the start of the project

Team was formed with special focus on diversity in terms of Experience, Knowledge, and Skills

Team identified and set realistic goals

Job Allocation was relevant

\section{Exploratory Factor Analysis}

In order to identify the underlying factor structure of the items pertinent to team effectiveness, Exploratory Factor Analysis (EFA) technique was utilized to represent the large pool of items as a smaller number of factors (Fabrigar, \& Wegener, 2011). This study used principal component analysis with varimax rotation. As recommended by Leech, Barrett, and Morgan (2005) the minimum factor loading was set to .50. Communalities statistics showed that all communalities were over the required value of .50. The factor solution derived initially yielded a total of 10 factors of Team Effectiveness that accounted for $73.828 \%$ of the variation in the data.

Exploratory factor analysis requires a number of assumptions to be met. First, the critical assumption is to test whether the data matrix has sufficient correlations. A visual examination of the correlation matrix was conducted to identify if there are ample number of significant correlations, Assessment of the correlation matrix revealed that almost all the correlations were significant with majority of the correlations were significant at $P<.001$, thus providing an excellent footing for factor analysis. Following the examination of the correlation matrix, next step involved weighing the overall significance of the correlation matrix through Bartlett test of sphericity, providing the statistical probability that the correlation matrix has significant correlations among at least some of the variables. The results were significant, $\chi^{2}(n=157)=$ 
$6626.518(P<.001)$, a clear indication of suitability for factor analysis. The Kaiser-Meyer-Olkin measure of sampling adequacy (MSA), a measure of the data set's appropriateness for factor analysis, was .89. Data sets with MSA values above .80 are considered appropriate for factor analysis (Hair, Andreson, Tatham, \& Black, 1998).

Two items “Team Members provided constant update on the progress towards tasks” and "Proper Selection process was undertaken to form the team" were removed cue to cross loading (> .50). Four items "Job Allocation was relevant”, "Team members were found to be emotionally Intelligent”, “Team was Self-Motivated to give something back to the society", and "Team members collaborate with each other to attain the task" were removed since it failed to load onto its respective factor. Two items "Team members had good Communication Skills" and "Leaders gave realistic challenge to the team members" were removed as the loading was not significant $(<.50)$. A total of eight items were removed during exploratory factor analysis.

After removal of the items that cross loaded, not loading onto their respective factor, and not loading significantly on any of the factor, factor analysis was carried out again. The results of exploratory factor analysis revealed a total of seven factors as shown in table 3 . The KaiserMeyer-Olkin MSA was .896. This exploratory factor analysis showed that the seven dimensions explained a total of $70.44 \%$ of the variance among the items in the study. The Bartlett's test of spherecity proved to be significant and all communalities were over the required value of .50.

Table 3. Factors derived from Exploratory Factor Analysis

\begin{tabular}{lllllll}
1 & 2 & 3 & 4 & 5 & 6 & 7 \\
\hline
\end{tabular}

\section{Inter Team Coordination}

Team members were pro-active

Team members were accommodating towards each other's needs

.805

There was significant Coherence/Unity among team members $\quad$.644

There was Harmony in the team

.786

Team Members were responsive to the needs of the co-workers $\quad .619$

Team Members understood each other feelings $\quad .615$

$\begin{array}{ll}\text { Team Members were quick learners } & .798\end{array}$

Team member showed zeal for continuous improvement $\quad .773$

\section{Community/Social Linkage}

Team members integrated well into the society $\quad .738$

Team members wanted to make a difference to the society $\quad .664$

Team Members had knowledge about community and society $\quad .709$

There was no significant conflict reported with the community $\quad .750$

Team members showed respect towards community and their culture $\quad$.798

Team developed good relationship with the community $\quad .793$

$\begin{array}{ll}\text { Team Understood Issues and challenges in the Society } & .738\end{array}$

Team Performance

The team was able to attain their targets in time 


\begin{tabular}{lc}
\hline Team members were not overloaded with work & .747 \\
No significant member left the team during the course of the project & .726 \\
Resources were used adequately with minimal losses & .636 \\
Team members showed integrity in using the resources & .649 \\
The team collectively was able to bring out a positive change in the & .687 \\
society through the project &
\end{tabular}

\section{Knowledge, Skills, and Attitudes}

Team members showed varied and complimentary

Skillset/Competencies required for the project

Members were sincere towards the team .683

Members realized their potential and worked to the best of their
abilities

$\begin{array}{ll}\text { Team members believed in healthy competition } & .582\end{array}$

Team members were held Responsible/Accountable for their tasks $\quad .570$

$\begin{array}{ll}\text { Team members enjoyed mutual Coordination } & .577\end{array}$

$\begin{array}{ll}\text { Team members respected each other } & .783\end{array}$

\section{Leader Communication and Engagement}

Leaders motivated sub-ordinates to achieve the project objectives $\quad .794$

Leader continuously followed-up the pace of activities $\quad .831$

Leaders took members opinion and discussed about problems in the
field

Leaders connected with stakeholders in the society $\quad .723$

Leader delegated power and responsibility to work independently $\quad .615$

Decision Making and Information Sharing

Team members gave their input when required in the decision

making process

Team members shared their knowledge and experiences $\quad .835$

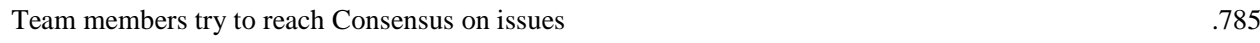

Team members shared their ideas in an open environment $\quad .793$

Team member actively participated in the team tasks $\quad .786$

\section{Team Formation}

Clear Direction and Focus was established right at the start of the project

Each of the team members clearly understood their job right at the start of the project

Team was formed with special focus on diversity in terms of

Experience, Knowledge, and Skills

The first factor was labeled as "Inter Team Coordination" and accounted for $12.821 \%$ of the variance. The factor was defined by a total of eight items with factor loadings ranging from .543 to .805. This dimension seeks to examine the team member behaviors that support NGO project delivery. The behaviors included pro-activeness, unity, conflicts, sharing and understanding, being responsive, learning, and continuous improvement. 
The second factor was labeled as "Community/Social Linkage" and accounted for $12.168 \%$ of the variance. The factor was defined by a total of seven items with factor loadings ranging from .664 to .798. Community/Social Linkage dimension seeks to appraise whether the team enjoyed effective society/community link. The dimension included items pertinent to integration, contribution to the society, conflict, knowledge, respect, network, issues and challenges.

The third factor labeled as team performance accounted for $10.723 \%$ of the variance and had a total of seven items. The dimension measures the performance of the team through indicators such as attainment of targets, society happiness, integrity in utilizing resources, turnover during the course of the project, loss resources, work overload, and positive change in the society.

The next factor was labelled as "Knowledge, Skills, and Attitudes". The factor accounted for $10.30 \%$ of the variance and consisted of a total of seven items. The factors measures the knowledge, skills, and attitudes of the people working in the team. KSA is measured through indicators such as skillset, sincerity, potential, believe in competition, responsibility/accountability, coordination, and respect.

The fifth factor was labelled as Leader communication and engagement which accounted for $9.046 \%$ of the variance and consisted of a total of five items. This factor examines the leader behaviors during the course of the project indicated through motivation, continuous follow-up, taking opinion and discussion, connection with society, and delegation of power.

The next factor was titled decision making and information sharing. The dimension accounted for a total of $8.679 \%$ of the variance and consisted of a total of five items. The dimension intends to measure how effective is the decision making and information sharing among the team. This is indicated through input, sharing knowledge and experience, reaching consensus on issues, sharing ideas in an open environment and active participation.

The last factor identified during exploratory factor analysis was named as team formation. The dimension accounted for a total of $6.706 \%$ of the variance and consisted of a total of four items. The indicators of effective team formation included clarity of direction and focus, understanding of job, diversity in team and realistic goals.

\section{Confirmatory Factor Analysis}

Confirmatory factor analysis was then utilized to assess the measurement model, data quality including construct reliability and construct validity. A measurement model was developed based on the results of exploratory factor analysis. A total of 43 items were part of the structural model.

Initially items were checked for low loadings and higher standardized residual covariance. Four items were removed due to low loadings. One from Inter team coordination "There was significant Coherence among team members", one from Knowledge, Skills, and Attitudes "Members realized their potential and worked to the best of their abilities", one from Leadership communication and engagement "Leader delegated power and responsibility to work independently" and one from Team Formation "Clear Direction and Focus was established right 
at the start of the project”. Three items were removed due to higher Standardized Residual Covariance, which was found to be over the recommended value of 2 . The items included one from Decision Making and Information Sharing "Team members gave their input when required in the decision making process”, one from Knowledge, Skills, and Attitudes “Team members were held Responsible/Accountable for their tasks" and one from Team Performance "Team members were not overloaded with work”. The results of CFA on the 36 items showed a good fit to the data. The results are in table 4.

Table 4. Fit Indices

\begin{tabular}{lcc}
\hline Fit Indices & Recommended Value & Obtained Value \\
\hline$\chi^{2} / \mathrm{df}$ & & $963.4 / 566$ \\
$\mathrm{P}$ & In-Significant & .000 \\
CMIN & $<=5$ & 1.702 \\
SRMR & $<=.08$ & .06 \\
RMSEA & $<=.06$ & .06 \\
CFI & $>=.90$ & .90 \\
TLI & $>=.90$ & .89 \\
\hline
\end{tabular}

Based on the indices revealed after confirmatory factor analysis, the results summarized in the above Table indicated an acceptable fit for the seven-factor model. A number of different ways were utilized to evaluate overall fit of the model to the data. When $P$ for $\chi^{2}$ is above a certain value (usually set to $P>.05$ ) an exact fit of a model is indicated. According to Arbuckle and Wothke (1999) $\mathrm{P}$ value is not suitable for model evaluation because no model fits perfectly. Another measure to evaluate model fit included the relative likelihood ratio (CMIN). Ullman (2001) suggested a relative likelihood ratio of less than 2. A number of other goodness-of-fit measures were also proposed. The present study utilizes SRMR, RMSEA, CFI and TLI. For SRMR, the smaller the value the good is the fit. L.-t. Hu and Bentler (1998) suggested that the value of SRMR should not excel .08. According to Byrne (2001) RMSEA is One of the most informative indices in SEM. The RMSEA value in the present study was .06, indicating an acceptable fair fit. (L. t. Hu \& Bentler, 1999) recommend value of RMSEA to be less than or equal to .06 for good fit. Values for CFI was over .90 while for TLI the value was very close to .90. Therefore, it was concluded that the seven-factor model fits the data well. The model is shown in the figure 1. 


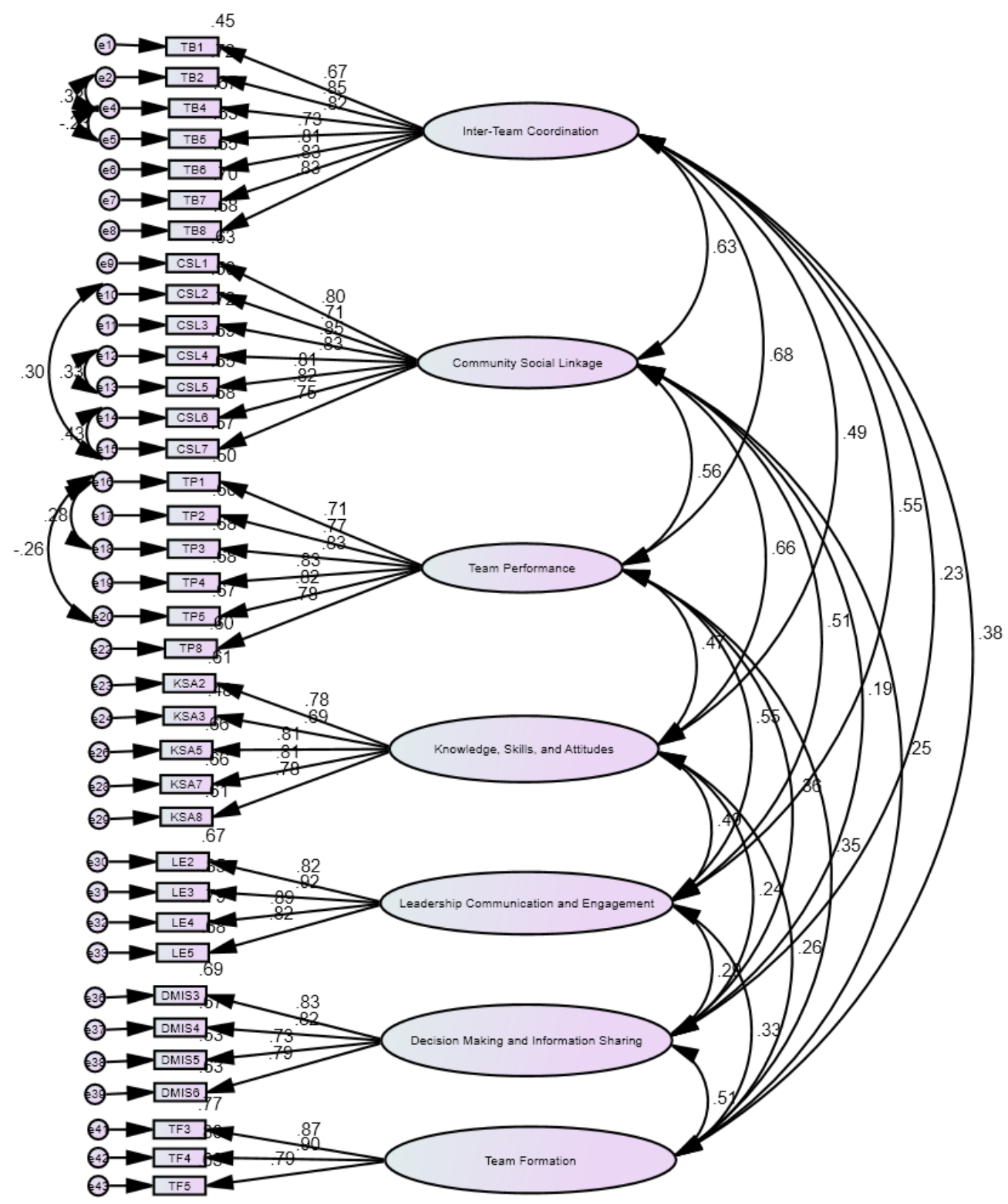

Figure 1. Output of Path Model for Team Effectiveness

\section{Reliability and Validity Analysis}

Further to the confirmatory factor analysis, in order to assess the internal consistency of the constructs, reliability analysis was conducted. Composite Reliability coefficient was reported 
to assess the reliability for the factors. As shown in the following table, the value for reliability ranged between .87 and .92, this shows that measures in the study were reliable (Hair, Sarstedt, Ringle, \& Mena, 2012).

Further to reliability analysis, convergent validity is established using Average Variance Extracted (Aga, Noorderhaven, \& Vallejo; Hair et al., 2012). Convergent validity is established if an AVE of .50 or greater is attained (Fornell \& Larcker, 1981; Sweeney \& Soutar, 2001). The results show that AVE for all constructs is over .50, thus convergent validity is achieved.

Table 5. Composite Reliability and AVE

\begin{tabular}{lcc}
\hline Construct & Composite Reliability & AVE \\
\hline Inter Team Coordination (ITB) & .92 & .62 \\
Community Social Linkage (CSL) & .92 & .63 \\
Team Performance (TP) & .90 & .62 \\
Knowledge, Skills, and Attitudes (KSA) & .88 & .60 \\
Leadership Communication and Engagement (LCE) & .92 & .74 \\
Decision Making and Information Sharing (DMIS) & .87 & .62 \\
Team Formation (TF) & .89 & .73 \\
\hline
\end{tabular}

Further to establishment of convergent validity, discriminant validity is established. According to Zikmund, Babin, Carr, and Griffin (2013) discriminant validity is established when a scale that should not correlate too highly with a measure of a different dimension actually do not have a high correlation value. According to Fornell and Larcker (1981) discriminant validity is established when AVE for each construct is greater than squared inter-correlations with other constructs. The results in Table 6 shows that the AVE was greater than the squared correlation coefficients between each pairs of constructs. These results provide strong evidence for discriminant validity.

Table 6. Discriminant Validity

\begin{tabular}{|c|c|c|c|c|c|c|c|}
\hline & ITC & CSL & TP & KSA & LCE & DMIS & TF \\
\hline ITC & .62 & & & & & & \\
\hline CSL & .39 & .63 & & & & & \\
\hline ТP & .45 & .31 & .62 & & & & \\
\hline KSA & .23 & .43 & .22 & .60 & & & \\
\hline LCE & .30 & .25 & .29 & .23 & .74 & & \\
\hline DMIS & .05 & .03 & .13 & .05 & .08 & .62 & \\
\hline TF & .14 & .06 & .12 & .06 & .10 & .26 & .73 \\
\hline
\end{tabular}

\section{Discussion}

Although the academic literature provides a number of different measures that identify the critical dimensions of team effectiveness for instance Multi-national corporations, engineering/business student, nursing \& medical students, construction, and product development (Kirkman and Shapiro, 1997; Brewer and Mendelson, 2003; Yang \& Chu, 2012; Kwofie et al., 2015; Parker, 2016), as far as we are aware based on the search of peer reviewed journals, there is no research that examines team effectiveness in NGO related projects. The paper is based on an original study that addresses the current gap in the understanding of teamwork. It is particularly valuable for teams in NGO based projects. Recently research has focused on NGO project management (PM) practices (Golini, Kalchschmidt, \& Landoni, 2015) 
and this has led to focus on teamwork as a critical factors in success of projects (Steinfort \& Walker, 2007). This study extends existing research on NGO Projects by identifying seven underlying dimensions of team effectiveness.

Inter team coordination dimension examines behaviors conducive to team effectiveness: pro-activeness, unity, conflicts, sharing and understanding, being responsive, learning, and continuous improvement. The factor analysis results showed that Team members were accommodating towards each other's needs had strongest association to the team behaviors factor followed by Team Members. The dimension of inter team coordination is extensively supported in the extant literature and has been identified in a number of definitions put forth by different researchers on the concept of team effectiveness (Cohen \& Bailey, 1997; Hackman, 1990; Ulloa \& Adams, 2004; Volmer \& Sonnentag, 2011; Wageman et al., 2005). Hoegl and Gemuenden (2001) stressed that team behaviors can result in collaboration and quality while Baiden and Price (2011) noted that behaviors can promote an environment where information is freely exchanged among the various parties. Furthermore positive team behaviors can induce support the formulation of practical recommendations (Willems, 2016).

Community/Social Linkage dimension seeks to appraise whether the team had effective society/community link: integration, contribution to the society, conflict, knowledge, respect, network, issues and challenges. The dimension is critical for NGO team effectiveness as social projects require an effective linkage with the society or community in order to achieve intended outcomes. The factor analysis results showed that the item Team members showed respect towards community and their culture had strongest association to the community social linkage followed by Team developed a network with community. These findings are in agreement with Yalegama et al. (2016) who highlighted the role of community in attaining greater project impact. Linkage with the society is further necessitated by the fact that it is imperative to have a local contact network. The network with the community can be off advantage since meeting people would help in making sense of direction (Brière, Proulx, Flores, \& Laporte, 2015). The importance of linkage with the society is further highlighted by Brière et al. (2015) who noted that teams should have the competency to develop a link with the society where the project is being carried out. Khang and Moe (2008) identified effective consultations with stakeholders to be a critical factor in success of the development projects. Lin Moe and Pathranarakul (2008) has identified participation of the clients or target beneficiaries critical for ensuring successful outcomes. The need for strong community/social linkage is further emphasized by the fact that developmental projects is the complex web of the many stakeholders involved (Youker, 1999) and One of the reason for failure of World Bank projects is poor stakeholder management (Ahsan \& Gunawan, 2010).

Team Performance dimension measures the performance of the team through indicators such as attainment of targets, society happiness, integrity in utilizing resources, turnover during the course of the project, loss resources, work overload, and positive change in the society. The factor analysis results showed that the item the society for which the project was intended was happy with the project had strongest association to the community social linkage followed by the team was able to attain their targets in time. Team performance has been identified as a key ingredient of team effectiveness (Cohen \& Bailey, 1997; Gladstein, 1984; Volmer \& Sonnentag, 2011; Wageman et al., 2005) with almost all the measures on team effectiveness have a dimension on team performance (Gordon et al., 2016; Guchait et al., 2016; Kirkman \& Shapiro,
Comment [D9]: Reviewer 1 Comments: In the discussion, the originality of the research has been further strengthened.

Originality Enhanced 
1997; Wageman et al., 2005; Yang \& Chu, 2012). According to Meredith Ross, Jones, and Adams (2008) team effectiveness consists of two overarching dimensions: team performance and team development. Haar, Segers, \& Jehn (2013) in their study to measure team effectiveness in emergency management teams found team performance to be the most significant dimension of team performance.

Knowledge, Skills, and Attitudes are measured through indicators such as skillset, sincerity, potential, believe in competition, responsibility/accountability, coordination, and respect. The factor analysis results showed that the item Team members respected each other had strongest association to the community social linkage followed by the Team members believed in healthy competition. Existing studies on team effectiveness has identified team attitudes as a key element to team effectiveness (Cohen \& Bailey, 1997; Delgado Piña, María Romero Martínez, \& Gómez Martínez, 2008; Kwofie et al., 2015). Attitude is an important process in the social structure of an organization. Right attitude can significantly impact the success of organizational endeavors. However, the present research found through exploratory factor analysis a single dimension that was linked to Knowledge and Skills, apart from just team attitudes. Knowledge, Skills, and Attitudes has been pointed out as an important element for effective team process (Converse, 1993). Liu, Pirola-Merlo, Yang, \& Huang (2009) showed that team coaching had positive effects on team performance processes regarding effort, skill and knowledge, which in turn had a direct impact on team effectiveness. Eisele (2015) found use of knowledge and skills to be a critical factor in team effectiveness.

Leader communication and engagement factor measures how effective is the team leader during the course of the project. The effectiveness of the team lead during the project was indicated through motivation, continuous follow-up, taking opinion and discussion, connection with society, and delegation of power. Research is rampant with arguments that clearly highlight the importance of leadership in teams. McDonough (2000) stressed that project leadership delineates task boundaries thus allowing the members to perform within those boundaries. Leader are vital to share information and knowledge within the team and they can enhance commitment by instilling a positive attitude and climate that helps to achieve project success. Aga et al. (2016) noted that leadership is required in order to induce team-building. Even if the organization assembles a high performing project team having the right knowledge, skills, and attitudes, absence of leadership will lead to failure (Burke et al., 2006). Effective leadership represents the most critical factor in the success of organizational teams (Lorinkova, Pearsall, \& Sims, 2013) . Project success can also be determined by the leadership style of the project manager (Müller \& Turner, 2010). Slootweg (2016) identified leadership as an important construct to teamwork. Team leadership can facilitate a team member's capability to monitor his or her teammates' performance (Salas, Stagl, Burke, \& Goodwin, 2007). This can be key in NGO projects that are facing failures (Golini, Kalchschmidt, \& Landoni, 2015).

Decision making and information sharing dimension intends to measure how effective is the decision making and information sharing among the team. This is indicated through input, sharing knowledge and experience, reaching consensus on issues, sharing ideas in an open environment and active participation. Role of collective decision making is emphasized by Stoner (1968) who noted that groups acting collaboratively will tend to take riskier decisions than individuals. The attitudinal benefit of decision making in teamwork is identified by Randeree and Ninan (2011) who noted that the involvement of team members in team decision- 
making increases their self-worth and motivation. Where (Mulec \& Roth, 2005) and (Woodhead, 2011) have clearly identified the role of decision making in teams. Mesmer-Magnus and DeChurch (2009) in their meta-analysis of 72 independent studies that were conducted over 22 years identified the value that team information sharing and decision making bring into effective teams. They found that Information sharing is a central process through which team members collectively utilize their available informational resources and information sharing holds a one of the key driver in team performance. Similarly, Braun et al. (2013) point out that successful project performance requires trustful interaction and communication between team members.

The findings of this research extends findings beyond the traditionally examined attitudes, behaviors, and performance indicators by identifying team formation to be a dimension of NGO project team effectiveness (Eisele, 2015). The indicators of effective team formation included clarity of direction and focus, understanding of job, diversity in team and realistic goals. Literature does identify the role of team formation in leading to effective team outcomes however existing research have yet to focus on the dimension. Edwards, Day, Winfred and Bell (2006) found a strong direct relationship between team composition and performance also highlights the importance of this factor. Team formation can have firsthand influence in shaping team performance, it can also have far reaching effects on the team member's attitudes and behaviors since with the right blend of people and complimentary skill set the team members attitudes and behaviors will be adequately nurtured.

\section{Contributions of the Study}

This study contributes to the literature in the following areas: Identification of project team effectiveness in NGOs, identification of team effectiveness in Pakistan, a country with limited project management capabilities. Although there has been significant amount of research on the determinants of team effectiveness as shown in Table 1, little extant work has examined effectiveness in NGO based projects. This study offers detailed insight into the key dimensions of team effectiveness in NGO based projects along with the identification of elements for each dimensions. The study found good support for the psychometric properties in terms of content, reliability, convergent, and discriminant validity. Further, this study was conducted in the country context of Pakistan, an area in which relatively little Project Management research has been conducted. The Community/Social dimension identified suggests that project team leaders play a role in developing collaborative social capacity (Nanthangopan and Williams 2016) which can provide valuable tacit knowledge to ensure successful project outcomes.

These dimensions can help NGO based organizations, practitioners and researchers to assess the degree of effectiveness in teams and focus on improvement efforts of the team. For researchers, the research findings contribute to further theoretical development in project management by identifying of the dimensions and elements that make up those dimensions of team effectiveness in developing countries such as Pakistan.

For practitioners these dimensions identified can be used to evaluate how effectively the team has been functioning and focus factors that needs improvement. Since many countries rely on NGOs to the study offers significant insights to aid in management of important initiatives that
Comment [D10]: Reviewer 1 Comments: How do this research contribute to the advancement of knowledge for NGOs project management?

How do these factors contribute to improved teams management in the field?

Author's Response: Based on the two comments from Reviewer 1, a new section titled Contribution of the study has been added in the study to highlight the contribution of the study. 
have far reaching effects not only for the project based organization but also for the donors, government and the community.

The research will help in developing an understanding of the practical difficulties that could prevent the effective functioning of the team in NGO based projects. While the need to develop competencies in project team members has been identified by previous research( Rehman eta al 2011) , the proposed dimensions with their measures can help design initiatives that develop the capacity to obtain successful project outcomes.

\section{Limitations and Future Research Directions}

The research has some limitations that should be mentioned. First, although the instrument has been developed from the inputs of extant literature, members working in NGOs, and community members, future studies may also involve corporations/businesses which fund different NGO based projects and representatives from the government. Second, the design of this research did not allow the gathering of longitudinal information. So, possible variations in perception about team effectiveness before, during, and after the projects could not be registered. Future studies may use the finding of the presented study to collect data at different points in time during the project and assess how the perception of team effectiveness varies along the course of the project. Future research could examine the perceptions of other stakeholders for instance employees who are not directly involved in different projects such as IT, finance, or human resource department. Lastly future research could also compare findings across different developing countries that have NGOs operating in them. In this way the validity of the team effectiveness model could be established and use as the basis for the design of evidence based practitioner tools.

\section{Conclusion}

There is a newfound expectation that NGOs or the 'third' sector is better placed as compared to the other stakeholders to provide leadership for social reconstruction in the developing world in particular (Mathieu et al., 2006). Most research has focused on identifying what affects effectiveness, instead of the dimensions and the variable (Delgado Piña, María Romero Martínez, \& Gómez Martínez, 2008). The present research aimed at identifying the underlying dimensions of NGO project team effectiveness. The study utilized both Literature and focus group discussions to generate items for NGO project team effectiveness. Exploratory and Confirmatory factor analysis revealed a total of seven factors namely: Inter team coordination, community/social linkage, team performance, knowledge, skills, and attitudes, leadership communication and engagement, decision making and information sharing, and team formation. The study found leadership communication and engagement and team formation to be completely new addition to the dimensionality of team effectiveness. Theoretically the importance of these two dimensions are well documented however none of the popular existing tools have referred to these as a dimension of team effectiveness. For NGO projects, this also study clearly highlights the importance of taking the community onboard and developing a strong linkage that would help in attaining project success through effective teams.

\section{Appendix 1}

\begin{tabular}{ll}
\hline S. No NGO Projects \\
\hline
\end{tabular}




\begin{tabular}{lc}
\hline 1 & Women Empowerment Projects \\
2 & Learning and Development Projects \\
3 & Health Projects \\
4 & Disaster and Humanitarian Projects \\
5 & Children Support Projects \\
6 & Economic Development Projects \\
\hline
\end{tabular}

\section{Appendix 2}

\section{Interview Questions}

1. How do you determine if a team is effective?

2. What attitudes from team members would you like to see in your team?

3. What behaviors of team members would you like your team to show?

4. What are the characteristics of an effective team?

5. How would you know if your team is performing up to the required level?

6. What Characteristics of Teams are required in Social Projects that are different from Commercial/Business Projects?

7. What behaviors and attitudes do you require in your team to meet the resilience that you face from the society?

\section{References}

Aga, D. A., Noorderhaven, N., \& Vallejo, B. (2016). Transformational leadership and project success: The mediating role of team-building. International Journal of Project Management, 34(5), 806-818.

Ahsan, K., \& Gunawan, I. (2010). Analysis of cost and schedule performance of international development projects. International Journal of Project Management, 28(1), 68-78.

Alexander, M. (1985). The team effectiveness critique. The 1985 annual: Developing human resources, 101-106.

Arbuckle, J. L., \& Wothke. (1999). AMOS 4.0 User's Guide. Chicago: Small Waters Corp.

Armony, V. (2008). La société civile et le développement. P. Haslam, J. Schafer, \& P. Beaudet (édit.), Introduction au développement international approches, acteurs et enjeux, 197211.

Azmy, N. (2012). The role of team effectiveness in construction project teams and project performance.

Baiden, B. K., \& Price, A. D. (2011). The effect of integration on project delivery team effectiveness. International Journal of Project Management, 29(2), 129-136

Bateman, B., Wilson, F., \& Bingham, D. (2002). Team effectiveness-development of an audit questionnaire. Journal of Management Development, 21(3), 215-226.

Baviskar, B. S. (2001). NGOs and civil society in India. Sociological Bulletin, 50(1), 3-15.

Belout, A., \& Gauvreau, C. (2004). Factors influencing project success: the impact of human resource management. International journal of project management, 22(1), 1-11.

Brewer, W., \& Mendelson, M. I. (2003). Methodology and metrics for assessing team effectiveness.

Brière, S., Proulx, D., Flores, O. N., \& Laporte, M. (2015). Competencies of project managers in international NGOs: Perceptions of practitioners. International Journal of Project Management, 33(1), 116-125. 
Brown, D., \& Korten, D. (1989). Understanding voluntary organizations. World Bank Working Papers WPS, 258.

Burke, C. S., Stagl, K. C., Klein, C., Goodwin, G. F., Salas, E., \& Halpin, S. M. (2006). What type of leadership behaviors are functional in teams? A meta-analysis. The Leadership Quarterly, 17(3), 288-307.

Busseri, M. A., \& Palmer, J. M. (2000). Improving teamwork: the effect of self-assessment on construction design teams. Design Studies, 21(3), 223-238.

Byrne, B. M. (2001). Structural Equation Modeling with AMOS, Basic Concepts, Applications, and Programming. Hillsdale, New Jersey: Lawrence Erlbaum Associates.

Campion, M. A., Medsker, G. J., \& Higgs, A. C. (1993). Relations between work group characteristics and effectiveness: Implications for designing effective work groups. Personnel psychology, 46(4), 823-847.

Castka, P., Bamber, C., \& Sharp, J. (2003). Measuring teamwork culture: the use of a modified EFQM model. Journal of Management Development, 22(2), 149-170.

Child, J. T., \& Shumate, M. (2007). The impact of communal knowledge repositories and people-based knowledge management on perceptions of team effectiveness. Management Communication Quarterly, 21(1), 29-54.

Chou, L.-F., Wang, A.-C., Wang, T.-Y., Huang, M.-P., \& Cheng, B.-S. (2008). Shared work values and team member effectiveness: The mediation of trustfulness and trustworthiness. Human Relations, 61(12), 1713-1742.

Cohen, S. G., \& Bailey, D. E. (1997). What makes teams work: Group effectiveness research from the shop fIoor to the executive suite. Journal of Management, 23(3), 239-290.

Converse, S. (1993). Shared mental models in expert team decision making. Individual and group decision making: Current(1993), 221.

Crawford, P., \& Bryce, P. (2003). Project monitoring and evaluation: a method for enhancing the efficiency and effectiveness of aid project implementation. International Journal of Project Management, 21(5), 363-373.

Dedu, V., Staicu, G., Niţescu, D.C., (2011). A critical examination of foreign aid policy. Why it fails to eradicate poverty? Theoretical and Applied Economics, 4(4), 37-48

Delgado Piña, M. I., María Romero Martínez, A., \& Gómez Martínez, L. (2008). Teams in organizations: a review on team effectiveness. Team Performance Management: An International Journal, 14(1/2), 7-21.

Demkin, J. A. (2008). The architect's handbook of professional practice. Hoboken (NJ): John Wiley \& Sons.

Diallo, A., \& Thuillier, D. (2004). The success dimensions of international development projects: the perceptions of African project coordinators. International Journal of Project Management, 22(1), 19-31.

Drucker, P. F. (2004). Managing the non-profit organization: Practices and principles: Taylor \& Francis.

Edwards, B. D., Day, E. A., Winfred, A. Jr and Bell, S. T. (2006). Relationship among team ability composition, team mental models, and team performance, Journal of Applied Psychology, 91(3), 727-736.

Eisele, P. (2015). The predictive validity of the team diagnostic survey: Testing a model with performance and satisfaction as output variables. Team Performance Management, 21(5/6), 293-306.

Fabrigar, L. R., \& Wegener, D. T. (2011). Exploratory factor analysis. Oxford University Press. 
Finn, R., Currie, G., \& Martin, G. (2010). Team work in context: institutional mediation in the public-service professional bureaucracy. Organization Studies, 31(8), 1069-1097.

Fornell, C., \& Larcker, D. F. (1981). Structural equation models with unobservable variables and measurement error: Algebra and statistics. Journal of marketing research, 382-388.

Friesen, L. D., Vidyarthi, A. R., Baron, R. B., \& Katz, P. P. (2008). Factors associated with intern fatigue. Journal of general internal medicine, 23(12), 1981-1986.

Ghosh, B. (2009). NGOs, Civil Society and Social Reconstruction in Contemporary India. Journal of Developing Societies, 25(2), 229-252.

Gibson, C. B., Zellmer-Bruhn, M. E., \& Schwab, D. P. (2003). Team Effectiveness in Multinational Organizations Evaluation Across Contexts. Group \& Organization Management, 28(4), 444-474.

Gladstein, D. (1984). Groups in context: a model of task group effectiveness. Administrative Science Quarterly, 29(4), 499-517.

Golini, R., Kalchschmidt, M., \& Landoni, P. (2015). Adoption of project management practices: the impact on international development projects of non-governmental organizations. International Journal of Project Management, 33(3), 650-663.

Gordon, C. J., Jorm, C., Shulruf, B., Weller, J., Currie, J., Lim, R., \& Osomanski, A. (2016). Development of a self-assessment teamwork tool for use by medical and nursing students. BMC Medical Education, 16(1), 218.

Guchait, P., Lei, P., \& Tews, M. J. (2016). Making Teamwork Work: Team Knowledge for Team Effectiveness. The Journal of psychology, 150(3), 300-317.

Haar, S. V. D., Segers, M., \& Jehn, K. A. (2013). Measuring the effectiveness of emergency management teams: scale development and validation. International Journal of Emergency Management, 9(3), 258-275.

Hackman, J. R. (1990). Groups that work and those that don't: Jossey-Bass.

Hair, J., Andreson, R., Tatham, R., \& Black, W. (1998). Multivariate data analysis. 5th (ed) Prentice-Hall Inc. Unites States of America.

Hair, J. F., Sarstedt, M., Ringle, C. M., \& Mena, J. A. (2012). An assessment of the use of partial least squares structural equation modeling in marketing research. Journal of the academy of marketing science, 40(3), 414-433.

Heap, S. (2000). NGOs engaging with business: A world of difference and a difference to the world: Intrac Oxford.

Herman, R. D., \& Renz, D. O. (2008). Advancing nonprofit organizational effectiveness research and theory: Nine theses. Nonprofit Management and Leadership, 18(4), 399-415.

Hernandez, Y., \& Cormican, K. (2016). Towards the Effective Management of Social Innovation Projects: Insights from Project Management. Procedia Computer Science, 100, 237-243.

Hoegl, M., \& Gemuenden, H. G. (2001). Teamwork quality and the success of innovative projects: A theoretical concept and empirical evidence. Organization science, 12(4), 435449.

Hu, L.-t., \& Bentler, P. M. (1998). Fit indices in covariance structure modeling: Sensitivity to underparameterized model misspecification. Psychological methods, 3(4), 424.

Hu, L. t., \& Bentler, P. M. (1999). Cutoff criteria for fit indexes in covariance structure analysis: Conventional criteria versus new alternatives. Structural equation modeling: $a$ multidisciplinary journal, 6(1), 1-55. 
Hutchinson, A., Cooper, K. L., Dean, J. E., McIntosh, A., Patterson, M., Stride, C. B., ... \& Smith, C. M. (2006). Use of a safety climate questionnaire in UK health care: factor structure, reliability and usability. Quality and Safety in Health Care, 15(5), 347-353.

Hüttermann, H., \& Boerner, S. (2011). Fostering innovation in functionally diverse teams: The two faces of transformational leadership. European journal of work and organizational psychology, 20(6), 833-854.

Ika, L. A., Diallo, A., \& Thuillier, D. (2012). Critical success factors for World Bank projects: An empirical investigation. International Journal of Project Management, 30(1), 105116.

Khan, Z. A., Thornton, N., \& Frazer, M. (2000). Experience of a financial reforms project in Bangladesh. Public Administration \& Development, 20(1), 33.

Khang, D. B., \& Moe, T. L. (2008). Success criteria and factors for international development projects: A life-cycle-based framework. Project Management Journal, 39(1), 72-84.

Killen, C.P., Jugdev, K., Drouin, N. and Petit, Y., 2012. Advancing project and portfolio management research: Applying strategic management theories. International Journal of Project Management, 30(5), pp.525-538.

Kirkman, B. L., \& Shapiro, D. L. (1997). The impact of cultural values on employee resistance to teams: Toward a model of globalized self-managing work team effectiveness. Academy of Management Review, 22(3), 730-757.

Klein, C. (2012). Research will evolve, but we must do a better job of translating what we already know. Industrial and Organizational Psychology, 5(1), 52-55.

Kozlowski, S. W., \& Ilgen, D. R. (2006). Enhancing the effectiveness of work groups and teams. Psychological science in the public interest, 7(3), 77-124.

Krishna, R., \& He, H. (2015). Managing team innovation in the research and development (R\&D) organization: Critical determinants of team effectiveness. Therapeutic Innovation \& Regulatory Science, 49(6), 877-885.

Kwofie, T. E., Alhassan, A., Botchway, E., \& Afranie, I. (2015). Factors contributing towards the effectiveness of construction project teams. International Journal of Construction Management, 15(2), 170-178.

Leech, N. L., Barrett, K. C., \& Morgan, G. A. (2005). SPSS for intermediate statistics: Use and interpretation. Psychology Press.

Levi, D. (2007). Group dynamics for teams.(2nd). Edition. Publisher: SAGE PUBN.

Lin Moe, T., \& Pathranarakul, P. (2006). An integrated approach to natural disaster management: public project management and its critical success factors. Disaster Prevention and Management: An International Journal, 15(3), 396-413.

Lorinkova, N. M., Pearsall, M. J., \& Sims, H. P. (2013). Examining the differential longitudinal performance of directive versus empowering leadership in teams. Academy of Management Journal, 56(2), 573-596.

Loughry, M. L., Ohland, M. W., \& Moore, D. D. (2007). Development of a theory-based assessment of team member effectiveness. Educational and Psychological Measurement, 67(3), 505-524.

Lin Moe, T., \& Pathranarakul, P. (2006). An integrated approach to natural disaster management: public project management and its critical success factors. Disaster Prevention and Management: An International Journal, 15(3), 396-413. 
Liu, C. Y., Pirola-Merlo, A., Yang, C. A. \& Huang, C. (2009). Disseminating the functions of team coaching regarding research and development team effectiveness: evidence from a high-tech industry in Taiwan, Social Behavior and Personality, 37(1), 41-58.

Levie, F., Burke, C. M., \& Lannon, J. (2016). Filling the gaps: An investigation of project governance in a non-governmental organisation's response to the Haiti earthquake disaster. International Journal of Project Management.

Macaulay, S., \& Cook, S. (1995). Practical teamwork for customer service. Team Performance Management: An International Journal, 1(3), 35-41.

Mathieu, J., Maynard, M. T., Rapp, T., \& Gilson, L. (2008). Team effectiveness 1997-2007: A review of recent advancements and a glimpse into the future Journal of Management, 34(3), 410-476.

McComb, S., Kennedy, D., Green, S., \& Compton, W. (2008). Project team effectiveness: the case for sufficient setup and top management involvement. Production Planning \& Control, 19(4), 301-311.

McDonough, E. F. (2000). Investigation of factors contributing to the success of cross-functional teams. Journal of product innovation management, 17(3), 221-235.

Meredith Ross, T., Jones, E. C., \& Adams, S. G. (2008). Can team effectiveness be predicted? Team Performance Management: An International Journal, 14(5/6), 248-268.

Mesmer-Magnus, J. R., \& DeChurch, L. A. (2009). Information sharing and team performance: a meta-analysis. Journal of Applied Psychology, 94(2), 535.

Mohrman, S. A., Cohen, S. G., \& Mohrman, A. M. (1995). Designing team-based organizations: new forms for knowledge work. San Francisco: Jossey-Bass.

Mueller, F. (1994). Teams between hierarchy and commitment: change strategies and the 'internal environment'. Journal of Management Studies, 31(3), 383-403.

Mueller, F., Procter, S., \& Buchanan, D. (2000). Teamworking in its context(s): antecedents, nature and dimensions. Human Relations, 53(11), 1387-1424.

Müller, R., Turner, R., 2010. Leadership competency profiles of successful project managers. International Journal of Project Management, 28, 437-448

Mulec, K., \& Roth, J. (2005). Action, reflection, and learning-coaching in order to enhance the performance of drug development project management teams. R\&D Management, 35(5), 483-491.

Nanthagopan, Y., Williams, N. L., \& Page, S. (2016). Understanding the nature of Project Management capacity in Sri Lankan non-governmental organisations (NGOs): A Resource Based Perspective. International Journal of Project Management, 34(8), 16081624.

Navarro-Flores, O. (2011). Organizing by projects: A strategy for local development-The case of NGOs in a developing country. Project Management Journal, 42(6), 48-59.

OECD (2015). G20/OECD Principles of Corporate Governance.

Parker, H. (2016). Team effectiveness and open discussion of conflict in collaborative new product development: A cross-national study. Journal of Business Research.

Piña, M. I. D., Martínez, A. M. R., \& Martínez, L. G. (2008). Teams in organizations: a review on team effectiveness. Team Performance Management: An International Journal, $14(1 / 2), 7-21$.

PMI, A. (2013). Guide to the Project Management Body of Knowledge-PMBOK Guide, Newtown Square, PA, USA: Project Management Institute. 
Procter, S., \& Currie, G. (2004). Target-based teamworking: groups, work and interdependence in the UK civil services. Human Relations, 57(12), 1547-1572.

Rahman, M. (2007). NGO management and operation: A south Asian perspective. Journal of Health Management, 9(2), 223-236.

Ramachandran, V., \& Walz, J. (2015). Haiti: Where has all the money gone?. Journal of Haitian Studies, 21(1), 26-65.

Randeree, K., \& Ninan, M. (2011). Leadership and teams in business: a study of IT projects in the United Arab Emirates. International Journal of Managing Projects in Business, 4(1), 28-48.

Rao, M. S. (2016). Collaborate to build effective teams to achieve organizational excellence and effectiveness. Industrial and Commercial Training, 48(1), 24-28.

Ronalds, P. (2012). The change imperative: creating the next generation NGO: Kumarian Press.

Ross, M. T., Jones, E. C., \& Adams, S. G. (2008). Can team effectiveness be predicted? Team Performance Management: An International Journal, 14(5/6), 248-268.

Salas, E., Stagl, K. C., Burke, C. S., \& Goodwin, G. F. (2007, January). Fostering team effectiveness in organizations: Toward an integrative theoretical framework. In Nebraska Symposium on Motivation (Vol. 52, p. 185).

Santos, J. P., Caetano, A., \& Tavares, S. M. (2015). Is training leaders in functional leadership a useful tool for improving the performance of leadership functions and team effectiveness? The Leadership Quarterly, 26(3), 470-484.

Schrader, S., \& Göpfert, J. (1996). Structuring manufacturer-supplier interaction in new product development teams: An empirical analysis: International Motor Vehicle Program, Massachusetts Institute of Technology.

Senior, B., \& Swailes, S. (2007). Inside management teams: Developing a teamwork survey instrument. British Journal of Management, 18(2), 138-153.

Shah, F. (2016, August 11). The rise of NGO's and their harmful impact on Pakistan. Retrieved April 16, 2017, from http://herald.dawn.com/news/1152863

Shaw, R., KOBAYASHl, M., Kameda, H., Gupta, M., Sharma, A., Nakagawa, Y., \& Banba, M. (2002). International cooperation in a post-disaster scenario: A case study from Gujarat, India. Journal of natural disaster science, 24(2), 73-82.

Shea, G. P., \& Guzzo, R. A. (1987 Spring). Group effectiveness: What really matters? Sloan Management Review, 25-31.

Sheppard, A., Tatham, P., Fisher, R., \& Gapp, R. (2013). Humanitarian logistics: enhancing the engagement of local populations. Journal of Humanitarian Logistics and Supply Chain Management, 3(1), 22-36.

Shih, C. P., \& Putri, D. U. (2016). Measuring the Effect of Team Characteristics, Team Effectiveness on Organizational Performance, Organizational Survival and Competitiveness: A Case Study of an Indonesian NGO, Yayasan Cinta Anak Bangsa by using PLS Method. International Journal of Asian Business and Information Management (IJABIM), 7(2), 1-14.

Simkhovych, D. (2009). The relationship between intercultural effectiveness and perceived project team performance in the context of international development. International Journal of Intercultural Relations, 33, 383-390.

Slootweg, I. A. (2016). Teamwork of clinical teachers in postgraduate medical training. Perspectives on Medical Education, 5(4), 253-256. 
Steinfort, P., \& Walker, D. (2007). Critical success factors in project management globally and how they may be applied to aid projects. Paper presented at the PMOZ Achieving Excellence-4th Annual Project Management Australia Conference.

Stoner, J. A. (1968). Risky and cautious shifts in group decisions: The influence of widely held values. Journal of Experimental Social Psychology, 4(4), 442-459.

Struyk, R. J. (2007). Factors in successful program implementation in Russia during the transition: pilot programs as a guide. Public Administration and Development, 27(1), 6383.

Sundstrom, E., DeMeuse, K. P., \& Futrell, D. (1990). Work teams: Applications and effectiveness. American Psychologist, 45, 120-133.

Sweeney, J. C., \& Soutar, G. N. (2001). Consumer perceived value: The development of a multiple item scale. Journal of retailing, 77(2), 203-220.

Tierney, K. (2012). Disaster governance: Social, political, and economic dimensions. Annual Review of Environment and Resources, 37, 341-363.

Todorović, M. L., Petrović, D. Č., Mihić, M. M., Obradović, V. L., \& Bushuyev, S. D. (2015). Project success analysis framework: A knowledge-based approach in project management. International Journal of Project Management, 33(4), 772-783.

Ullman, S. (2001). In BG Tabachnick, \& LS Fidell (Eds.), Using multivariate statistics (pp. 653771 ed., p. 966): Needham Heights, MA: Allyn and Bacon.

Ulloa, B. C. R., \& Adams, S. G. (2004). Attitude toward teamwork and effective teaming. Team Performance Management: An International Journal, 10(7/8), 145-151.

Unger-Aviram, E., Zwikael, O., \& Restubog, S. L. D. (2013). Revisiting goals, feedback, recognition, and performance success: The case of project teams. Group \& Organization Management, 38(5), 570-600.

Valentine, M. A., Nembhard, I. M., \& Edmondson, A. C. (2015). Measuring teamwork in health care settings: a review of survey instruments. Medical care, 53(4), e16-e30.

Vickland, S., \& Nieuwenhuijs, I. (2005). Critical success factors for modernising public financial management information systems in Bosnia and Herzegovina. Public Administration and Development, 25(2), 95-103.

Volmer, J., \& Sonnentag, S. (2011). The role of star performers in software design teams. Journal of Managerial Psychology, 26(3), 219-234.

Wageman, R., Hackman, J. R., \& Lehman, E. (2005). Team diagnostic survey development of an instrument. The Journal of Applied Behavioral Science, 41(4), 373-398.

Wang, L., MacCann, C., Zhuang, X., Liu, O. L., \& Roberts, R. D. (2009). Assessing teamwork and collaboration in high school students: A multimethod approach. Canadian Journal of School Psychology, 24(2), 108-124.

Willems, J. (2016). Building shared mental models of organizational effectiveness in leadership teams through team member exchange quality. Nonprofit and Voluntary Sector Quarterly, 45(3), 568-592.

Woodhead, V. (2011). How does coaching help to support team working? A case study in the NHS. International Journal of Evidence Based Coaching and Mentoring, 5, 102-119.

Yalegama, S., Chileshe, N., \& Ma, T. (2016). Critical success factors for community-driven development projects: A Sri Lankan community perspective. International Journal of Project Management, 34(4), 643-659.

Yang, X., \& Chu, X. (2012). People value for team effectiveness in China: the mediating role of leader identification. Nankai Business Review International, 3(1), 65-74. 
Youker, R. (1999). Managing international development projects--lessons learned.

Zetland, D. (2010). Save the poor, shoot some bankers. Public Choice, 145(3-4), 331-337.

Zhu, Y., \& Purnell, D. (2006). Multinational NGOs and expatriation: A case study of a NGO in Vietnam. Asia Pacific Business Review, 12(4), 529-546.

Zikmund, W. G., Babin, B. J., Carr, J. C., \& Griffin, M. (2013). Business research methods: Cengage Learning. 